\title{
Determining the Net Present Value of Timber Investments and Comparing Investments of Different Rotations ${ }^{1}$
}

\author{
Andres Susaeta and Chris Demers ${ }^{2}$
}

The economic valuation of forests is necessary for several reasons. For example, value of a forest operation can be used to determine the sale or purchase price of a forest during a commercial transaction or the amount of taxes owed to the IRS when selling timber or the forest. Accurate economic valuation is essential for comparisons of different pine or hardwood species rotation ages and/or different management intensities, as well as to determine the insurance value of a forest. Another important purpose of an economic assessment is to compare different timberland investments. This is particularly important when timber management projects have different time horizons. For example, would a forest landowner be economically better off growing a forest for pulpwood production with a short rotation instead of growing the same forest for sawtimber production with a longer rotation? In this publication, we will provide the standard methods used to conduct a comparative analysis of timber investments of similar or unequal time horizons, namely the net present value $(N P V)$ approach and the equivalent annuity approach (EAA), respectively.

\section{The Net Present Value (NPV) Approach for Projects of Equal Length}

The NPV determines the difference between the present value of cash inflows of timber benefits and the present value of cash outflows of silvicultural and management costs over a period of time. The timber benefits are realized in the future when the forest stand is thinned or finally harvested, and some silvicultural costs and management costs can be also incurred in the future as the forest stand is growing. Therefore, both costs and returns need to be discounted back to the present over $T$ years of the forest stand. A discount rate (also called interest rate to take into account the time value of money) is decided on to solve for $N P V$. If we consider a single rotation of $T$ years, the net present value $(N P V)$ of a forest stand for timber production can be defined as:

$N P V=P V B-P V C$

1. This document is FOR352, one of a series of the School of Forest Resources and Conservation, UF/IFAS Extension. Original publication date November 2019. Visit the EDIS website at https://edis.ifas.ufl.edu for the currently supported version of this publication.

2. Andres Susaeta, assistant research scientist; and Chris Demers, forest stewardship coordinator, School of Forest Resources and Conservation; UF/IFAS Extension, Gainesville, FL 32611.

The Institute of Food and Agricultural Sciences (IFAS) is an Equal Opportunity Institution authorized to provide research, educational information and other services

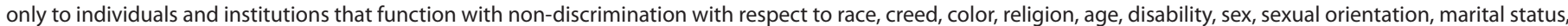

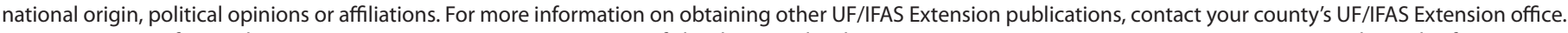
U.S. Department of Agriculture, UF/IFAS Extension Service, University of Florida, IFAS, Florida A \& M University Cooperative Extension Program, and Boards of County Commissioners Cooperating. Nick T. Place, dean for UF/IFAS Extension. 
where $P V B$ and $P V C$ are the present value of the sum of timber benefits and sum of costs, respectively, since the establishment of the forest stand until the forest stand is clearcut. The $P V B$ and $P V C$ can be represented as follows:

$$
\begin{aligned}
& P C B=\sum_{t=1}^{T} \frac{A_{t}}{(1+r)^{t}} \\
& P V C=C_{0}+\sum_{t=1}^{T} \frac{C_{t}}{(1+r)^{t}}+C_{i}\left[\frac{(1+r)^{T}-1}{r(1+r)^{T}}\right]
\end{aligned}
$$

Where $A_{t}$ is the economic revenues due to thinning benefits and final harvest of the stand; $C_{0}$ is the establishment costs (site preparation and planting costs at stand age 0 ); $C_{t}$ is the intermediate costs to grow the stand at time $t$ (e.g., fertilization, marking, thinning costs); $C_{i}$ is the annual management or administrative costs; $r$ is the discount rate; and $T$ is the final harvest age.

Let's consider the following forest investments in slash pine and loblolly pine stands (Table 1). It is assumed that the slash pine and loblolly pine stands are planted at time $t=$ 0 and harvested at age $T=25$ years. Both stands produce three forest products: sawtimber, chip-and-saw, and pulpwood. Silvicultural activities, with their associated current costs and revenues (cash flows), occur at the times specified in Table 1. A discount rate $r=0.05(5 \%)$ is also assumed.

Table 1. Costs and Revenues ( $\$$ per acre) of Silvicultural Activities in Slash and Loblolly Pine Stands.

\begin{tabular}{|l|c|c|c|}
\hline \multirow{2}{*}{ Activity } & Age (years) & \multicolumn{2}{c|}{ Revenue (cost) \$ per acre } \\
\cline { 2 - 4 } & & slash & loblolly \\
\hline Establishment & 0 & $(400)$ & $(400)$ \\
\hline Fertilization & 5,15 & $(70),(70)$ & $(70),(70)$ \\
\hline Thinning & 15 & 232 & 363 \\
\hline Annual costs & $1-20$ & $(20)$ & $(20)$ \\
\hline Final harvest & 25 & 4490 & 4432 \\
\hline
\end{tabular}

Prices of sawtimber (\$27.0), chip-and-saw $(\$ 18.9)$ and pulpwood (\$10.4) per ton obtained from Timber Mart South (2018). Yields of sawtimber, chip-and-saw and pulpwood for slash pine and loblolly pine are provided by Pienaar et al. (1996) and Harrison and Borders (1996), respectively. Cost of thinnings is assumed to be $20 \%$ of the stumpage prices. Thinning yields (slash) of. 4.7 (chip-and-saw) and 18.9 (pulpwood) tons per acre; thinning yields (loblolly) of 11.7 (chip-and-saw) and 21.3 tons (pulpwood) per acre (loblolly). Harvest yields (slash) of 85.0 (sawtimber), 98.5 (chip-and-saw) and 22.5 (pulpwood) tons per acre; harvest yields (loblolly) of 208.8 (sawtimber), 80.3 (chip-and-saw) and 100.1 (pulpwood) tons per acre.
The NPV of single rotation for timber production is: (see Table 2)

Following the $N P V$ criterion, timber investment in loblolly pine is preferred over a timber investment in slash pine because $N P V$ associated with loblolly pine ( $\$ 731$ per acre) is higher than the $N P V$ associated with slash pine ( $\$ 667$ per acre).

\section{The Equivalent Annuity Approach (EAA) for Projects of Unequal Length}

The equivalent annuity approach $(E A A)$ is a method used to evaluate the economic viability of two or more timber investment projects of different lengths. It basically puts $N P V$ on an annualized basis. The EAA is defined as follows:

$$
E A A=\frac{r \times N P V}{\left(1-(1+r)^{-T}\right)}
$$

Example (a): let's assume a slash pine timber investment with an NPV of $\$ 672$ per acre over a 26-year rotation and a loblolly pine timber investment with an $N P V$ of $\$ 721$ per acre over a 23-year rotation. Is the slash pine investment better than the loblolly pine investment? In our example,

$E A A($ slash $)=0.05 \times 672 /\left(1[1.05]^{-26}\right)=\$ 46.7$

$E A A($ loblolly $)=0.05 \times 721 /\left(1[1.05]^{-23}\right)=\$ 53.5$

Following the EAA criterion, the loblolly pine project is a better option.

Example (b): is a slash pine investment with a $N P V$ of $\$ 667$ per acre with a rotation age of 25 years a better economic alternative compared to a loblolly pine investment with a NPV of $\$ 612$ per acre rotation age of 30 years? Example:

$$
\begin{aligned}
& E A A(\text { slash })=0.05 \times 667 /\left(1[1.05]^{-25}\right)=\$ 47.3 \\
& E A A(\text { loblolly })=0.05 \times 612 /\left(1[1.05]^{-30}\right)=\$ 39.8
\end{aligned}
$$

Therefore, it is better to invest in slash pine management. 
Example (c): let's assume, and just for practical purposes, that a loblolly pine project is a riskier investment compared to a slash pine project. This is reflected by a higher discount rate- $r=0.07$. With a $7 \%$ discount rate, the $N P V$ of a loblolly pine investment is $\$ 108$ per acre over a 30 year rotation. The slash pine investment is the same as in example (b) $(E A A=\$ 47.3)$. Under this new assumption,

$($ loblolly $)=0.07 \times 108 /\left(1[1.07]^{-30}\right)=\$ 8.7$

It is clear that it is not worth investing in loblolly pine and waiting the additional 5 years. Furthermore, we can see that a higher discount rate severely reduces the NPV and EAA of the loblolly pine investment. Compared to the loblolly pine investment in example (b), the NPV and EAA are reduced by $\$ 508$ per acre and $\$ 30$, respectively.

\section{Conclusions}

The net present value (NPV) of a single rotation of a forest stand provides the criterion to choose between different forest project investments of equal lives (equal rotation ages). This approach suggests that the best forest investment project is the one that yields the greatest $N P V$. The equivalent annuity approach $(E A A)$ is employed when forest project investments have different time lengths. Similar to the NPV approach, this criterion indicates that the best forest investment project is the one that yields the highest $E A A$. Because the discount rate can affect the NPV and $E A A$ values, it must be chosen wisely. In many cases one may use at least two discount rates to look at the discount rate change effect on $N P V$ or EAA.

\section{References}

Pienaar, L.V., B. D. Shiver, and J. W. Rheney. 1996. Yield

Prediction for Mechanically Site-Prepared Slash Pine Plantations in the Southeastern Coastal Plain. PMRC Technical Report 1996-3A, University of Georgia, Athens, GA.

Harrison, W., and B. Borders. 1996. Yield Prediction and Growth Projection Site-Prepared Loblolly Pine Plantations in the Carolinas, Georgia, Alabama, and Florida. PMRC Technical Report 1996-1.University of Georgia, Athens, GA.

Maggard, A., and R. Barlow. 2017. "2016 Costs and trends for southern forestry practices." Forest Landowner Magazine September/October, 31-39.

Timber Mart South. 2018. Us South Annual Review: 2018. University of Georgia Warnell School of Forestry and Natural Resources, Center for Forest Business, and Frank W. Norris Foundation, Athens, GA. 
Table 2. Determination of the Net Present Value (NPV) of Slash and Loblolly Pine Stands.

\begin{tabular}{|c|c|c|c|c|}
\hline & $\begin{array}{c}\text { Establishment } \\
C_{0}\end{array}$ & $\begin{array}{l}\text { Intermediate costs } \\
\qquad \sum_{t=1}^{T} \frac{C_{t}}{(1+r)^{t}}\end{array}$ & $\begin{array}{l}\text { Annual costs } \\
C_{i}\left[\frac{(1+r)^{T}-1}{r(1+r)^{T}}\right]\end{array}$ & $\begin{array}{c}\text { Thinning \& harvest } \\
\text { revenues } \\
\sum_{t=1}^{T} \frac{A_{t}}{(1+r)^{t}}\end{array}$ \\
\hline \multirow[t]{3}{*}{ slash } & 400 & $70 / 1.05^{5}+70 / 1.05^{15}$ & $20\left(1.05^{5}-1\right) / 0.05\left(1.05^{25}\right)$ & $232 / 1.05^{15}+4990 / 1.05^{25}$ \\
\hline & $=400$ & $=89$ & $=282$ & $=1438$ \\
\hline & \multicolumn{4}{|c|}{ NPV slash $=1438-400-89-282=\$ 667$ per acre } \\
\hline \multirow[t]{3}{*}{ loblolly } & 400 & $70 / 1.05_{5}+70 / 1.05^{15}$ & $20\left(1.05^{5}-1\right) / 0.05\left(1.03^{25}\right)$ & $363 / 1.05^{15}+4432 / 1.05^{25}$ \\
\hline & $=400$ & $=89$ & $=282$ & $=1483$ \\
\hline & \multicolumn{4}{|c|}{ NPV loblolly $=1483-400-89-282=\$ 731$ per acre } \\
\hline
\end{tabular}

